\title{
Anurans of a threatened savanna area in western Brazil
}

\author{
José Luiz Massao Moreira Sugai ${ }^{1,3}$, Juliana de Souza Terra ${ }^{1}$ \& Vanda Lúcia Ferreira ${ }^{2}$
}

${ }^{1}$ Pós Graduação em Ecologia e Conservação, Universidade Federal de Mato Grosso do Sul, Cidade Universitária, Caixa Postal 549, CEP 79070-900, Campo Grande, MS, Brasil. (jlmassao@gmail.com).

${ }^{2}$ Centro de Ciências Biológicas e da Saúde, Universidade Federal de Mato Grosso do Sul, Cidade Universitária, Caixa Postal 549, CEP 79070-900, Campo Grande, MS, Brasil.

${ }^{3}$ Corresponding author. José Luiz Massao Moreira Sugai - E-mail: jlmassao@gmail.com

SUGAI, J. L. M. M.; TERRA, J. S. AND FERREIRA, V. L. Anurans of a threatened savanna area in western Brazil. Biota Neotropica. 14(1): e20134058. biotaneotropica.org.br/v14n1/en/abstract?inventory+bn00314012014

\begin{abstract}
The Upper Paraguay River Basin is located in the center of South America and harbors one of the largest wetland in the world, known as Pantanal. This floodplain is surrounded by uplands, which presently have most of their area converted into pastures or monocultures, besides being poorly known scientifically. Also, most of these upland areas are considered conservation priorities. Here we present a list of anuran species from a savanna-like area (municipality of Camapuã, state of Mato Grosso do Sul, Brazil) inserted in the uplands surrounding the Pantanal floodplain, in the Upper Taquari River sub-basin, and evaluate the effectiveness of the sampling effort. Data were obtained through active searches in 22 plots in aquatic habitats, during the rainy season (from December 2009 to April 2010). We found 26 species, in four families. Although sampling effort was found to sufficiently represent the local anuran assemblage, future inventories in this region should ideally include samplings during the dry and early rainy seasons, and include both active and passive capturing methods.
\end{abstract}

Keywords: Amphibia, veredas, Upper Taquari River sub-basin, biological inventories, environmental degradation.

SUGAI, J. L. M. M.; TERRA, J. S. E FERREIRA, V. L. Anuros de uma ameaçada área de savana no oeste do Brasil. Biota Neotropica. 14(1): e20134058. biotaneotropica.org.br/v14n1/pt/abstract?inventory+bn00314012014

Resumo - A bacia do Alto Paraguai, localizada no centro da América do Sul, abriga uma das maiores áreas inundáveis do mundo, conhecida como Pantanal. Essa planície alagável é rodeada por planaltos, os quais possuem grande parte de sua área convertida em pastagens ou monoculturas, além de serem pouco conhecidos cientificamente. Além disso, a maioria das áreas de planalto são consideradas prioritárias para a conservação. Apresentamos uma lista de espécies de anuros de uma área semelhante a savanas (município de Camapuã, estado de Mato Grosso do Sul, Brasil) inserida nos planaltos de entorno do Pantanal, na sub-bacia do Alto Taquari, e avaliamos a efetividade do esforço amostral. Os dados foram obtidos através de busca ativa em 22 parcelas em ambientes aquáticos, durante a estação chuvosa (de Dezembro de 2009 a Abril de 2010). Encontramos 26 espécies, em quatro famílias. Apesar de considerarmos o esforço amostral suficiente para representar da comunidade de anuros local, sugerimos que futuros inventários nessa região contemplem a estação seca e início da chuvosa, bem como o uso adicional de métodos passivos de captura.

Palavras-chave: Amphibia, veredas, sub-bacia do Alto Taquari, inventários biológicos, degradação ambiental. 


\section{Introduction}

The Upper Paraguay River basin, located in the center of South America (Brazil, Paraguay and Bolivia), is an unique region for harboring the sedimentary depression known as Pantanal, one of the largest wetlands in the world (Harris et al. 2006). It is formed by the Paraguay River and its tributaries, which have headwaters in upland areas surrounding the floodplain (Harris et al. 2006, Galdino \& Vieira 2006). In the Brazilian part of the Upper Paraguay River basin, the fauna and flora consist mainly of species typical from the savanna-like Cerrado morphoclimatic domain (sensu Ab'Saber 1977), with influence from Amazon Forest in the northern region, Chaco in the southwestern region and Atlantic Forest in the southern region (Silva et al. 2000, Harris et al. 2006, Strüssmann et al. 2011).

Most of the Pantanal is still covered by natural vegetation (approximately 85\%) since the flooding cycles hinder the expansion of agriculture and livestock (WWF 2010). However, more than half of the upland area around it was converted into pastures or monocultures like cotton, soybean and sugar cane (WWF 2010). One of the most degraded upland areas is the Upper Taquari River sub-basin, with only $34.4 \%$ of the original vegetation (WWF 2010). The removal of native vegetation causes huge erosions due to the high soil fragility, besides silting streams and rivers (Galdino \& Vieira 2006). Most of the upland areas in Upper Paraguay River basin (including the Upper Taquari River sub-basin) are therefore considered priorities for conservation of Brazilian biodiversity and require both urgent reduction of environmental degradation and creation of conservation units (MMA 2007).

Environmental degradation is the main cause of worldwide biodiversity loss (Gibbons et al. 2000, Sala et al. 2000), which is not different regarding amphibians (Alford \& Richards 1999, Young et al. 2001, Cushman 2006). In the new world, habitat loss affects $89 \%$ of all threatened amphibian species and is about three times more dominant than any other threat (Young et al. 2004). Environmental degradation causes loss of breeding sites, shelter and connectivity between aquatic habitats, leading to population declines, local extinctions and changes in community structure (Cushman 2006). In areas subjected to high levels of environmental degradation, such as the Upper Taquari River subbasin, lots of data about natural history and distribution of anuran species are lost before being recorded, which leads to urgent need of field studies to record these information.

Most studies about anuran assemblages done in the Cerrado ecorregion (sensu Olson et al. 2001) are concentrated in its southeasternmost portion, with a lack of information about assemblages in other regions (Diniz-Filho et al. 2006). Information about the species richness and composition in the Upper Paraguay River basin are scarce (Strüssmann et al. 2000, Gordo \& Campos 2003, 2005, Uetanabaro et al. 2006, 2007, Souza et al. 2010, Pansonato et al. 2011), and records involving the Upper Taquari River sub-basin (Strüssmann et al. 2000, Uetanabaro et al. 2006) are even rarer. At least 90 anuran species are estimated to occur in the Upper Paraguay River basin, and new occurrences are expected particularly in poorly known areas (Strüssmann et al. 2011). Aiming at decreasing lack of knowledge on the anurofauna in this watershed, we present a list of species from a Cerrado area in the municipality of Camapuã (state of Mato Grosso do Sul), inserted in the Upper Taquari River sub-basin. To improve future samplings, we also present an evaluation of the quality of the sampling effort.

\section{Material and Methods}

We sampled aquatic habitats in the surroundings of Pontinha do Cocho (1901'07' S, 53 53'44”'W), a small village in the municipality of Camapuã, state of Mato Grosso do Sul, Brazil (Figure 1). The sampled area ins located in the Upper Taquari River sub-basin, which is part of the ecological corridor between the Pantanal floodplain and important conservation units in the Cerrado ecorregion (Emas National Park and Nascentes do Taquari State Park) (MMA 2007; Figure 1). Local rainy season lasts from October to March and the dry season, from May to September, and average annual rainfall is $1506 \mathrm{~mm}$ (Soriano \& Galdino 2006). The predominant human activity is cattle ranching, which requires large areas of pasture (Galdino \& Vieira 2006). The region presents phytophysiognomies ranging from forest to savanna, including riparian forests, marshes and pasture areas (Oliveira-Filho \& Ratter 2002, WWF 2010). Despite the predominance of degraded areas, there are fragments of riparian forests and marshes without the direct influence of livestock.

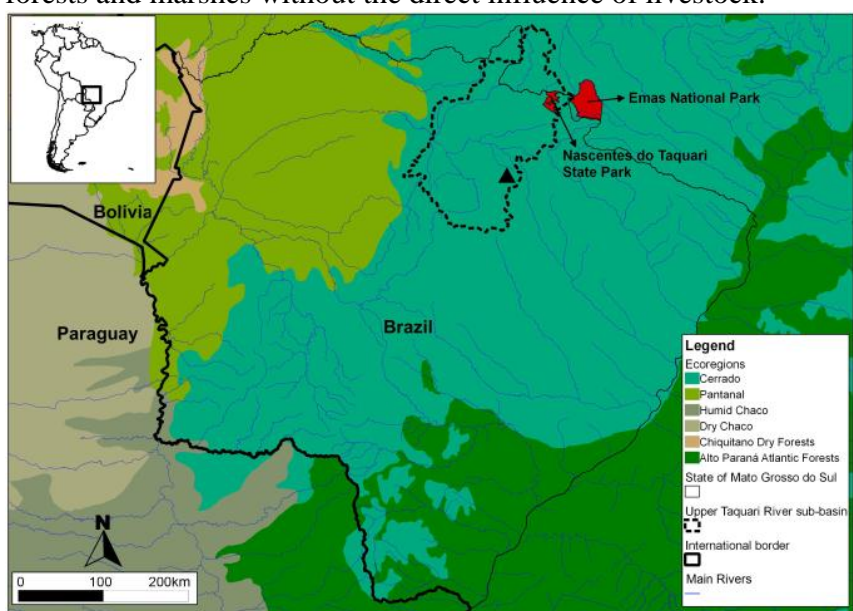

Figure 1. Map of the State of Mato Grosso do Sul, Brazil, with its location in South America showed in the upper left corner. The ecoregions follow the classification of Olson et al. (2001). The black triangle represents the location of the sampled area, inserted in the Upper Taquari River sub-basin (dashed line), which connects the Pantanal to important conservation units in the Cerrado (indicated in red).

Figura 1. Mapa do estado de Mato Grosso do Sul, Brazil, com sua localização na América do Sul mostrada no canto superior esquerdo. As ecorregiões seguem a classificação de Olson et al. (2001). O triângulo preto representa a localização da área amostrada, inserida na sub-bacia do Alto Taquari (linha tracejada), a qual liga o Pantanal a importantes unidades de conservação do Cerrado (indicadas em vermelho).

We sampled three types of aquatic habitats during the rainy season: veredas, permanent lagoons and temporary ponds. Veredas are marshy areas with slow running water, where groundwater emerges and is common the presence of the Buriti palm (Mauritia flexuosa L.f.) (Ribeiro \& Walter 1998). Permanent lagoons are large water bodies formed by impoundments of small streams or veredas, while temporary ponds are natural depressions with accumulated rainwater. We performed three consecutive field samplings, all of them after the onset of the rains: from December 20 to 25, 2009; from January 23 to February 1, 2010; from March 15 to April 10, 2010. We sampled 18 points at veredas, two at permanent lagoons and two at temporary ponds, totaling 22 points (Table 1). Four were sampled in the first field sampling, five in the second, and 13 in the third. Once at each point, immediately after the nightfall (between $18 \mathrm{~h} 30 \mathrm{~min}$ and $19 \mathrm{~h} 30 \mathrm{~min}$ ), two researchers actively searched for anurans (visually and acoustically; Crump \& Scott 1994), for three hours on average. 
Table 1. Geographic coordinates of the 22 sampled aquatic habitats in the surroundings of Pontinha do Cocho village, municipality of Camapuã, state of Mato Grosso do Sul, Brazil.

Tabela 1. Coordenadas geograficas das 22 localidades amostradas em três tipos de ambientes aquáticos no entorno do vilarejo de Pontinha do Cocho, município de Camapuã, stato de Mato Grosso do Sul, Brasil.

\begin{tabular}{|c|c|}
\hline Sampled location & Geographic coordinates \\
\hline Temporary pond 1 & $19^{\circ} 2^{\prime} 12.78^{\prime \prime S}, 53^{\circ} 53^{\prime} 44.92^{\prime \prime} \mathrm{W}$ \\
\hline Temporary pond 2 & $19^{\circ} 0^{\prime} 50.10^{\prime \prime} \mathrm{S}, 53^{\circ} 51^{\prime} 32.91^{\prime \prime} \mathrm{W}$ \\
\hline Permanent lagoon 1 & $19^{\circ} 0^{\prime} 52.38^{\prime \prime} \mathrm{S}, 53^{\circ} 51^{\prime} 29.89^{\prime \prime} \mathrm{W}$ \\
\hline Permanent lagoon 2 & $19^{\circ} 1^{\prime} 31.02^{\prime \prime} \mathrm{S}, 53^{\circ} 51^{\prime} 34.46^{\prime \prime} \mathrm{W}$ \\
\hline Vereda 1 & $19^{\circ} 2^{\prime} 55.44^{\prime \prime S}, 53^{\circ} 53^{\prime} 46.17^{\prime \prime} \mathrm{W}$ \\
\hline Vereda 2 & $19^{\circ} 1^{\prime} 19.26^{\prime \prime S}, 53^{\circ} 50^{\prime} 28.88^{\prime \prime} \mathrm{W}$ \\
\hline Vereda 3 & $19^{\circ} 0^{\prime} 35.89^{\prime \prime} \mathrm{S}, 53^{\circ} 51^{\prime} 40.38^{\prime \prime} \mathrm{W}$ \\
\hline Vereda 4 & $19^{\circ} 0^{\prime} 54.45^{\prime \prime} \mathrm{S}, 53^{\circ} 51^{\prime} 26.07^{\prime \prime} \mathrm{W}$ \\
\hline Vereda 5 & $19^{\circ} 3^{\prime} 14.97^{\prime \prime S}, 53^{\circ} 53^{\prime} 44.14^{\prime \prime} \mathrm{W}$ \\
\hline Vereda 6 & $19^{\circ} 1^{\prime} 15.08^{\prime \prime} \mathrm{S}, 53^{\circ} 50^{\prime} 9.95^{\prime \prime W}$ \\
\hline Vereda 7 & $19^{\circ} 2^{\prime} 46.79^{\prime \prime S}, 53^{\circ} 53 ' 51.03^{\prime \prime W}$ \\
\hline Vereda 8 & $19^{\circ} 5^{\prime} 58.58^{\prime \prime} \mathrm{S}, 53^{\circ} 52^{\prime} 5.49^{\prime \prime} \mathrm{W}$ \\
\hline Vereda 9 & $19^{\circ} 0^{\prime} 9.90^{\prime \prime} \mathrm{S}, 53^{\circ} 51^{\prime} 25.20^{\prime \prime} \mathrm{W}$ \\
\hline Vereda 10 & $19^{\circ} 0$ '28.35"S, 5351'25.19"W \\
\hline Vereda 11 & $19^{\circ} 1^{\prime} 38.70^{\prime \prime} \mathrm{S}, 53^{\circ} 50^{\prime} 47.39^{\prime \prime} \mathrm{W}$ \\
\hline Vereda 12 & $19^{\circ} 1^{\prime} 38.16^{\prime \prime} \mathrm{S}, 53^{\circ} 51^{\prime} 31.52^{\prime \prime} \mathrm{W}$ \\
\hline Vereda 13 & $19^{\circ} 2^{\prime} 16.01^{\prime \prime S}, 53^{\circ} 49^{\prime} 54.23^{\prime \prime} \mathrm{W}$ \\
\hline Vereda 14 & $19^{\circ} 0^{\prime} 45.23^{\prime \prime} \mathrm{S}, 53^{\circ} 52^{\prime} 3.19^{\prime \prime} \mathrm{W}$ \\
\hline Vereda 15 & $19^{\circ} 5^{\prime} 20.26^{\prime \prime} \mathrm{S}, 53^{\circ} 52^{\prime} 43.50^{\prime \prime} \mathrm{W}$ \\
\hline Vereda 16 & $19^{\circ} 2^{\prime} 8.26 " \mathrm{~S}, 53^{\circ} 50^{\prime} 23.04^{\prime \prime W}$ \\
\hline Vereda 17 & $19^{\circ} 1^{\prime} 28.34^{\prime \prime} \mathrm{S}, 53^{\circ} 51^{\prime} 30.82^{\prime \prime} \mathrm{W}$ \\
\hline Vereda 18 & $19^{\circ} 1^{\prime} 8.05^{\prime \prime S}, 53^{\circ} 50^{\prime} 32.78^{\prime \prime W}$ \\
\hline
\end{tabular}

We constructed a rarefaction curve based on the samples and using the software EstimateS version 8.2.0 and 1000 randomizations (Colwell 2006). Rarefaction curves represent the statistical expectation of species richness at different numbers of individuals or samples (Gotelli \& Colwell 2001). To evaluate the effectiveness of our sampling effort, we generated a nonlinear model from the rarefaction curve using the Clench equation: $S n=a \cdot n /(1+b \cdot n)$ (Soberón \& Llorente 1993). In this equation, $\mathrm{n}$ is the number of samples or individuals, $S n$ is estimated richness with $\mathrm{n}$ number of samples or individuals, and $a$ and $b$ are model parameters which determine the increase of species and the shape of the curve (Soberón \& Llorente 1993), respectively. Then, we estimated the percentage of total species estimated by the model and calculated the tangent at the largest sample size of the rarefaction curve (Jiménez-Valverde \& Hortal 2003). The tangent value represents the rate of species richness increase with higher sampling effort, and if it is small (near 0.1 ; above 0.3 can be considered high) few additional species are expected, even after larger sampling efforts (Jiménez-Valverde \& Hortal 2003). We calculated the proportion of the maximum richness and the tangent value using the $a$ and $b$ model parameters (Jiménez-Valverde \& Hortal 2003).

Voucher material of species that could not be correctly identified at the field was deposited at the zoological collection of Universidade Federal de Mato Grosso do Sul (ZUFMS AMP; Appendix 1). Tissue samples and recorded vocalizations were also deposited at ZUFMS (Appendix 2 and 3). License for collection and transportation of animals (number 23112-1) was provided by Instituto Chico Mendes de Conservação da Biodiversidade/Sistema de Autorização e Informação em Biodiversidade (ICMBio/SISBIO). Nomenclature follows Frost (2013).

\section{Results}

We found 26 species in 13 genera and four families (Table 2, Figure 2). The richest family was Hylidae (13 species), followed by Leptodactylidae (11 species). Bufonidae and Microhylidae were represented by only one species each. The rarefaction curve (Figure 3) did not reach an asymptote, but the tangent on the larger sample size was small (0.2). Moreover, the model estimates that we recorded $78 \%$ of the richness estimated at the asymptote, which can be considered a good sampling effort. Both the recorded tangent value and richness proportion indicate a small increase in species richness, with increasing sampling (Jiménez-Valverde \& Hortal 2003).

Table 2. Anuran families and species registered in the sampled aquatic habitats in the surroundings of Pontinha do Cocho village, municipality of Camapuã, state of Mato Grosso do Sul, Brazil. PL: permanent lagoon; TP: temporary pond; VE: vereda.

Tabela 2. Famílias e espécies de anuros registrados nos corpos d'água amostrados no entorno do vilarejo de Pontinha do Cocho, município de Camapuã, estado de Mato Grosso do Sul, Brasil. PL: lagoa permamente; TP: poça temporária; VE: vereda.

\begin{tabular}{|c|c|c|c|}
\hline Family/species & PL & $\mathrm{TP}$ & VE \\
\hline \multicolumn{4}{|l|}{ BUFONIDAE } \\
\hline Rhinella schneideri (Werner, 1894) & $\mathrm{X}$ & & \\
\hline \multicolumn{4}{|l|}{ HYLIDAE } \\
\hline Dendropsophus elianeae (Napoli \& & & & \\
\hline Caramaschi, 2000) & & $\mathrm{X}$ & $\mathrm{X}$ \\
\hline \multicolumn{4}{|l|}{$\begin{array}{l}\text { Dendropsophus jimi (Napoli \& Caramaschi, } \\
\text { 1999) }\end{array}$} \\
\hline Dendropsophus nanus (Boulenger, 1889) & $\mathrm{X}$ & $\mathrm{X}$ & $\mathrm{X}$ \\
\hline Dendropsophus minutus (Peters, 1872) & $\mathrm{X}$ & $\mathrm{X}$ & $\mathrm{X}$ \\
\hline Hypsiboas albopunctatus (Spix, 1824) & & & $\mathrm{X}$ \\
\hline Hypsiboas raniceps Cope, 1862 & $\mathrm{X}$ & $\mathrm{X}$ & $\mathrm{X}$ \\
\hline Hypsiboas aff. geographicus & & & $\mathrm{X}$ \\
\hline Hypsiboas punctatus (Schneider, 1799) & & & $\mathrm{X}$ \\
\hline Phyllomedusa azurea Cope, 1862 & $\mathrm{X}$ & $\mathrm{X}$ & \\
\hline Pseudis platensis Gallardo, 1961 & $\mathrm{X}$ & & $\mathrm{X}$ \\
\hline Scinax fuscovarius (Lutz, 1925) & $\mathrm{X}$ & & $\mathrm{X}$ \\
\hline Scinax fuscomarginatus (Lutz, 1925) & & $\mathrm{X}$ & $\mathrm{X}$ \\
\hline Trachycephalus typhonius (Linnaeus, 1758) & $\mathrm{X}$ & & $\mathrm{X}$ \\
\hline \multicolumn{4}{|l|}{ LEPTODACTYLIDAE } \\
\hline Adenomera cf. diptyx (Boettger, 1885) & & & $\mathrm{X}$ \\
\hline Eupemphix nattereri Steindachner, 1863 & $\mathrm{X}$ & $X$ & \\
\hline Leptodactylus furnarius & & & \\
\hline Bokermann, 1978 & & & $\mathrm{X}$ \\
\hline Leptodactylus fuscus (Schneider, 1799) & & & $\mathrm{X}$ \\
\hline Leptodactylus podicipinus (Cope, 1862) & & $X$ & $\mathrm{X}$ \\
\hline Leptodactylus latrans (Steffen, 1815) & & & $\mathrm{X}$ \\
\hline Leptodactylus mystacinus (Burmeister, 1861) & & & $\mathrm{X}$ \\
\hline $\begin{array}{l}\text { Physalaemus albonotatus (Steindachner, } \\
\text { 1864) }\end{array}$ & & $X$ & \\
\hline Physalemus cuvieri Fitzinger, 1826 & & & $\mathrm{X}$ \\
\hline $\begin{array}{l}\text { Pseudopaludicola ternetzi Miranda-Ribeiro, } \\
1937\end{array}$ & & & $\mathrm{X}$ \\
\hline Pseudopaludicola saltica (Cope, 1887) & & & $\mathrm{X}$ \\
\hline MICROHYLIDAE & & & \\
\hline Elachistocleis matogrosso Caramaschi, 2010 & & & $\mathrm{X}$ \\
\hline
\end{tabular}



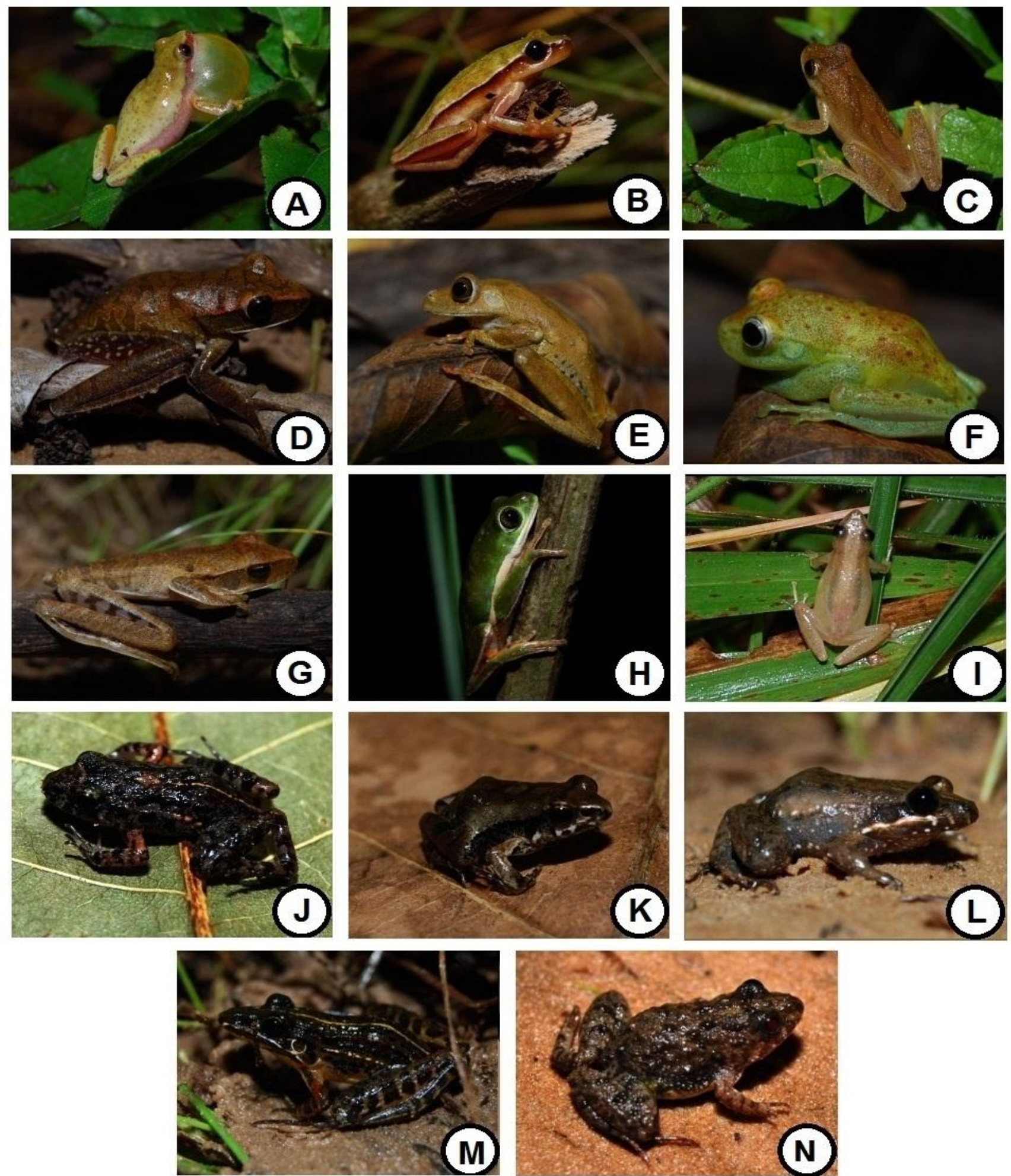

Figure 2. Photographs of some anuran species registered in the surroundings of Pontinha do Cocho village, municipality of Camapuã, Mato Grosso do Sul state, Brazil. A) Dendropsophus elianeae; B) D. jimi; C) D. minutus; D) Hypsiboas albopunctatus; E) H. aff. geographicus; F) H. punctatus; G) H. raniceps; H) Phyllomedusa azurea; I) Scinax fuscomarginatus; J) Adenomera cf. diptyx; K) Physalaemus cuvieri; L) Leptodactylus podicipinus; M) Leptodactylus furnarius; N) Pseudopaludicola ternetzi.

Figura 2. Fotografias de algumas espécies de anuros registradas no entorno do vilarejo de Pontinha do Cocho, município de Camapuã, estado de Mato Grosso do Sul, Brasil. A) Dendropsophus elianeae; B) D. jimi; C) D. minutus; D) Hypsiboas albopunctatus; E) H. aff. geographicus; F) H. punctatus; G) H. raniceps; H) Phyllomedusa azurea; I) Scinax fuscomarginatus; J) Adenomera cf. diptyx; K) Physalaemus cuvieri; L) Leptodactylus podicipinus; M) Leptodactylus furnarius; N) Pseudopaludicola ternetzi. 


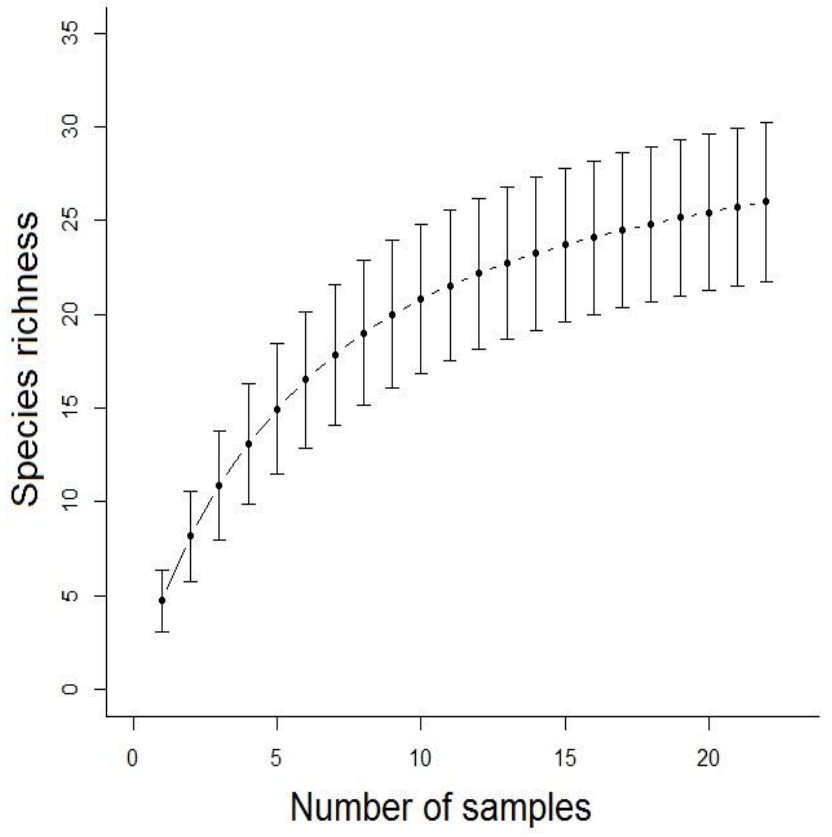

Figure 3. Rarefaction curve made for the 22 sampled points in the municipality of Camapuã, Mato Grosso do Sul state, Brazil. The vertical bars indicate the upper and lower limits of the $95 \%$ confidence interval.

Figura 3. Curva de rarefação feita para os 22 pontos amostrados no município de Camapuã, estado de Mato Grosso do Sul, Brasil. As barras verticais indicam o limite superior e inferior do intervalo de confiança de $95 \%$.

\section{Discussion}

All species registered in this study have already been recorded in the Upper Taquari River sub-basin (Strüssmann et al. 2000) or in nearby areas (Uetanabaro et al. 2006, Silva-Junior et al. 2009). Four out of the 26 species found (Dendropsophus jimi, Hypsiboas aff. geographicus, Leptodactylus furnarius and Pseudopaludicola ternetzi) have been rarely recorded in Mato Grosso do Sul. Dendropsophus jimi was recorded in the municipalities of Chapadão do Sul and Costa Rica (Uetanabaro et al. 2006). Hypsiboas aff. geographicus was recorded in the municipality of Coxim (Strüssmann et al. 2000) and in Amolar mountain range, municipality of Corumbá (Gordo \& Campos 2003, 2005). Our record for this species extends its distribution to nearly $150 \mathrm{~km}$ southeast of Coxim. Leptodactylus furnarius was recorded in the municipalities of Costa Rica (Uetanabaro et al. 2006) and Sonora (Silva-Junior et al. 2009). The record for P. ternetzi, confirmed by bioacustic data (Pansonato, A., unpublished data), is the first one for the species in Mato Grosso do Sul.

Phyllomedusa azurea and Pseudis paradoxa are classified as "Data Deficient" among the categories of the International Union for Conservation of Nature (IUCN) Red List (Angulo 2008a, b). The remaining species (except for Hypsiboas aff. geographicus) are classified as "Least Concern" (IUCN 2013). Hypsiboas aff. geographicus probably represents an undescribed species, for which few data are available (Strüssmann et al. 2000, Gordo e Campos 2005, Pansonato et al. 2011).

We did not sample during the dry season and early rainy season, which probably decreased the possibilities of recording some additional species expected for the region due to nearby records and availability of reproductive habitats (such as Hypsiboas lundii and species of the Rhinella granulosa group), mainly active during these periods (Strüssmann et al. 2000, Uetanabaro et al. 2006). Furthermore, active searches are not efficient for sampling fossorial and criptozoic taxa (Crump \& Scott 1994), and probably more species with these habits would have been recorded if we had used more than one sampling method (e.g., active search + pitfall traps). This region also harbors areas with mounds and rocky outcrops where associated species which do not occur in the aquatic habitats sampled - are expected to be found (Strüssmann et al. 2000, Uetanabaro et al. 2006).

Despite almost half of the species recorded during this study present taxonomic problems (Adenomer cf. diptyx: Heyer 1984, De la Riva 1996; Hypsiboas aff. geographicus: Duellman 1973) or may represent species complexes due to great morphological, bioacustic, chromosomal or genetic variation (Dendropsophus nanus: Medeiros et al. 2003, Reichle et al. 2004; D. minutus: Kaplan 1994, Hawkins et al. 2007; Hypsiboas punctatus: Napoli \& Cruz 2005; Scinax fuscovarius: Faivovich et al. 2005, Aquino et al. 2010; S. fuscomarginatus: Cardoso \& Pombal Jr. 2010, Pombal Jr. et al. 2011; Leptodactylus fuscus: Heyer \& Reid 2003, Camargo et al. 2006; L. latrans: Gallardo 1964, De la Riva \& Maldonado 1999, Heyer et al. 2010a; L. mystacinus: Heyer et al. 2003, Heyer et al. 2010b; Physalaemus albonotatus: Aquino et al. 2004, Jansen et al. 2011), nomenclature changes depend on future taxonomic revision. Well-resolved taxonomy and systematics are assumptions to identify species at risk and to improve the current knowledge about the diversity and distribution of species (Young et al. 2001, Aleixo 2009). Species richness reported in many inventories is underestimated due to cryptic species, which are sometimes revealed by including non-morphological characters in taxonomic analysis (Fouquet et al. 2007a, b). Although several recent studies have revised problematic taxonomic groups in Anura (e.g. Pseudopaludicola; Duarte et al. 2010, Fávero et al. 2011, Pansonato et al. 2012, 2013), there are still many in need of studies using integrative taxonomy, such as Adenomera and Scinax (Heyer 1984, Kwet 2007, Zaracho \& Hernando 2011, Nunes et al. 2012). Samplings in poorly known regions, such as that of the present study, contribute to taxonomic and systematic revisions with vouchers, vocalizations records, material for molecular analysis and species distribution data.

An increase in the species list for the Upper Taquari River subbasin is expected following additional samplings, especially in marsh or rocky outcrop areas, habitats not yet converted into pastures or monocultures. We suggest that future inventories in this region encompass both the dry and early rainy seasons and involve passive capture methods (e.g. pitfall traps) in addition to active searches. Despite the local environmental degradation and the lack of biological knowledge, this particular watershed is an important area for the conservation of Cerrado anuran assemblages because it harbors species that are poorly known scientifically. Furthermore, it is part of the ecological corridor between the Pantanal floodplain and important conservation units in the Cerrado (MMA 2007).

\section{Acknowledgements}

We thank to Fundação de Apoio ao Desenvolvimento do Ensino, Ciência e Tecnologia do Estado de Mato Grosso do Sul (FUNDECT no 0329/08) for the financial support; to José Tadachi Sugai and Marisa Paschoal M. Sugai for allowing the sampling on their property and for logistic support during the fieldwork. J.L.M.M.S. and J.S.T. thank to CAPES and CNPq, respectively, for scholarships. V.L.F. thanks CNPq for a research productivity fellowship (307360/2009-1). 


\section{References}

AB'SABER, A.N. 1977. Os domínios morfoclimáticos na América do Sul. USP/IGEOG, São Paulo, Geomorfologia 52:1-23.

ALEIXO, A. 2009. Conceitos de espécie e suas implicações para a conservação. Megadiversidade 5(1-2):87-95.

ALFORD, R.A. \& RICHARDS, S.J. 1999. Global amphibian declines: a problem in applied ecology. Ann. Rev. Ecol. Syst. 30:133-165.

ANGULO, A. 2008a. Pseudis platensis. In IUCN 2013. IUCN Red List of Threatened Species. Version 2013.2. http://www.iucnredlist.org (ultimo acesso em 13/12/2013).

ANGULO, A. 2008b. Phyllomedusa azurea. In IUCN 2013. IUCN Red List of Threatened Species. Version 2013.2. http://www.iucnredlist.org (ultimo acesso em 13/12/2013).

AQUINO, L., REICHLE, S., SILVANO, D. \& LANGONE, J. 2004. Scinax fuscovarius. In IUCN 2013. IUCN Red List of Threatened Species. Version 2013.2. http://www.iucnredlist.org (ultimo acesso em 13/12/2013).

AQUINO, L., BASTOS, R., REICHLE, S., SILVANO, D., BALDO, D. \& LANGONE, J. 2010. Scinax fuscovarius. In IUCN 2013. IUCN Red List of Threatened Species. Version 2013.2. http://www.iucnredlist.org (ultimo acesso em 13/12/2013).

CAMARGO, A., DE SÁ, R.O. \& HEYER, W.R. 2006. Phylogenetic analyses of mtDNA sequences reveal three cryptic lineages in the widespread neotropical frog Leptodactylus fuscus (Schneider, 1799) (Anura, Leptodactylidae). Biol. J. Linn. Soc. 87:325-341.

CARDOSO, M.W. \& POMBAL-JÚNIOR., J.P. 2010. A new species of small Scinax Wagler, 1830 (Amphibia, Anura, Hylidae) of the Scinax ruber clade from Cerrado of central Brazil. AmphibiaReptilia 31:411-418.

COLWELL, R.K. 2006. EstimateS: Statistical estimation of species richness and shared species from samples. Version 8.

CRUMP, M.L. \& SCOTT JR, N.J. 1994. Visual encounter surveys. In Measuring and Monitoring Biological Diversity Standard Methods for Amphibians (W. R. Heyer, M. A. Donnelly, R. W. McDiarmid, L. A. C. Hayek \& M. S. Foster, eds). Smithsonian Institution Press, Washington, p.84-92.

CUSHMAN, S.A. 2006. Effects of habitat loss e fragmentation on amphibians: a review e prospectus. Biol. Cons. 128:231-240.

DE LA RIVA, I. 1996. The specific name of Adenomera (Anura: Leptodactylidae) in the Paraguay River Basin. J. Herpetol. 30(4):556-558.

DE LA RIVA, I. \& MALDONADO, M. 1999. First record of Leptodactylus ocellatus (Lunnaeus, 1758) (Amphibia, Anura, Leptodactylidae) in Bolivia and comments on related species. Graellsia 55:193-197.

DINIZ-FILHO, J.A.F., BINI, L.M., RANGEL, T.F.L.V.B., CARVALHO, P., PINTO, M.P., COUTO, M.S.D.S. \& BASTOS, R.P. 2006. Conservation biogeography of anurans in Brazilian Cerrado. Biodivers. Conserv. 16:997-1008.
DUARTE, T.C., VEIGA-MENONCELLO, A.C.P., LIMA, J.F.R., STRÜSSMANN, C., DEL-GRANDE, M.L., GIARETTA, A.A., PEREIRA, E.G., ROSSA-FERES, D.C. \& RECCO-PIMENTEL, S.M. 2010. Chromosome analysis in Pseudopaludicola (Anura, Leiuperidae), with description of sex chromosomes $\mathrm{XX} / \mathrm{XY}$ in $P$. saltica. Hereditas 147:43-52.

DUELLMAN, W.E. 1973. Frogs of the Hyla geographica group. Copeia 1973(3):515-532.

FAIVOVICH, J., HADDAD, C.F.B., GARCIA, P.C.A., FROST, D.R., CAMPBELL, J.A., WHEELER, W.C. 2005. Systematic review of the frog family Hylidae, with special reference to Hylinae: phylogenetic analysis and taxonomic revision. Bull. Am. Mus. Nat. Hist. 294:1-240.

FÁVERO, E.R., VEIGA-MENONCELLO, A.C.P., ROSSA-FERES, D.C., STRÜSSMANN, C., GIARETTA. A.A., ANDRADE, G.V., COLOMBO, P. \& RECCO-PIMENTEL, S.M. 2011. Intrageneric karyotypic variation in Pseudopaludicola (Anura: Leiuperidae) and its taxonomic relatedness. Zool. Stud. 50(6):826-836.

FOUQUET A., GILLES, A., VENCES, M., MARTY, C., BLANC, M. \& GEMMELL, N.J. 2007a. Underestimation of species richness in Neotropical frogs revealed by mtDNA analyses. PLoS ONE 2(10):e1109.

FOUQUET, A., VENCES, M., SALDUCCI, M.D., MEYER, A., MARTY, C., BLANC, M. \& GILLES, A. 2007b. Revealing cryptic diversity using molecular phylogenetics and phylogeography in frogs of the Scinax ruber and Rhinella margaritifera species groups. Mol. Phylogenet. Evol. 43(2):567582.

FROST, D.R. 2013. Amphibian species of the world: an online regerence. Version 5.6 . http://research.amnh.org/herpetology/amphibia/index.html (ultimo acesso em 12/06/2013).

GALDINO, S. \& VIEIRA, L.M.. 2006. A Bacia do Rio Taquari e seus problemas ambientais e socioeconômicos. In Impactos ambientais e socioeconômicos na Bacia do Rio Taquari - Pantanal (S. Galdino, L.M. Vieira \& L.A. Pellegrin, eds.). Embrapa Pantanal, Corumbá, p.29-41.

GALLARDO, J.M. 1964. Consideraciones sobre Leptodactylus ocellatus (L.) (Amphibia, Anura) y especies aliadas. Physis 24(68): 373-384.

GIBBONS, J.W., SCOTT, D.E., RYAN, T.J., BUHLMANN, K.A., TUBERVILLE, T.D., METTS, B.S., GRANDENE, J.L., MILLS, T., LEIDEN, Y., POPPY, S. \& WINNE, C.T. 2000. The global decline of reptiles, deja-vu amphibians. Bioscience 50(8):653-667.

GORDO, M.; CAMPOS, Z. 2003. Listagem de anuros da Estação Ecológica Nhumirim e arredores, Pantanal Sul. Embrapa Pantanal, Série Documentos 58:1-21.

GORDO, M. \& CAMPOS, Z.M.S. 2005. Anuros das serras de entorno do Pantanal Sul. Embrapa Pantanal, Série Documentos 78:1-21. 
GOTELLI, N. \& COLWELL, R.K. 2001. Quantifying biodiversity: procedures and pitfalls in the measurement and comparison of species richness. Ecol. Lett. 4:379-391.

HARRIS, M.B.; ARCANGELO, C.; PINTO, E.C.T.; CAMARGO, G.; RAMOS-NETO, M.B. e SILVA, S.M. 2006. Estimativa da perda de cobertura vegetal original na Bacia do Alto Paraguai e Pantanal brasileiro: ameaças e perspectivas. Natur. Conserv. 4(2):164-179.

HAWKINS, M.A., SITES, J.W. \& NOONA, B.P. 2007. Dendropsophus minutus (Anura : Hylidae) of the Guiana Shield: using DNA barcodes to assess identity and diversity. Zootaxa 1540:61-67.

HEYER, W.R. 1984. The systematic status of Adenomera griseigularis Henle, with comments on systematic problems in the genus Adenomera (Amphibia, Leptodactylidae). Amphibia-Reptilia 5:97100 .

HEYER, M.M., HEYER, W.R., SPEAR, S. \& DE SÁ R.O. 2003. Leptodactylus mystacinus (Burmeister).Cat. Am. Amph. Rept. 767: 1-9.

HEYER, W.R. \& REID, Y.R. 2003. Does advertisement call variation coincide with genetic variation in the genetically diverse frog taxon currently known as Leptodactylus fuscus (Amphibia: Leptodactylidae)? An. Acad. Bras. Ciênc. 75(1):39-54.

HEYER, W.R., LANGONE, J., LA MARCA, E., AZEVEDORAMOS, C., DI TADA, I., BALDO, D., LAVILLA, E. NORMAN, S., AQUINO, L. \& HARDY, J. 2010a. Leptodactylus latrans. In IUCN 2013. IUCN Red List of Threatened Species. Version 2013.2. http://www.iucnredlist.org/ (ultimo acesso em $13 / 12 / 2013)$.

HEYER, W.R., SILVANO, D., REICHLE, S., LAVILLA, E. \& DI TADA, I. 2010b. Leptodactylus mystacinus. In IUCN 2013. IUCN Red List of Threatened Species. Version 2013.2. (ultimo acesso em 13/12/2013).

IUCN. 2013. The IUCN Red List of Threatened Species. http://www.iucnredlist.org (ultimo acesso em 13/12/2013).

JANSEN, M., BLOCH, R., SCHULZE, A. \& PFENNINGER, M. 2011. Integrative inventory of Bolivia's lowland anurans reveals hidden diversity. Zool. Scrip. 40(6):567-583.

JIMÉNEZ-VALVERDE, A. \& HORTAL, J. 2003. Las curvas de acumulación de especies y la necesidad de evaluar la calidad de los inventarios biológicos. Rev. Ibér. Aracnol. 8:151-161.

KAPLAN, M. 1994. A new species of frog of the genus Hyla from the Cordillera Oriental in northern Columbia with comments on the taxonomy of Hyla minuta. J. Herpetol. 28(1):79-87.

KWET, A. 2007. Bioacoustic variation in the genus Adenomera in southern Brazil, with revalidation of Leptodactylus nanus Müller, 1922 (Anura: Leptodactylidae). Mus. Nat. kd. Berl. Zool. 83:5668.

MEDEIROS, L.R., ROSSA-FERES, D.C. \& RECCO-PIMENTEL S.M. 2003. Chromosomal differentiation of Hyla nana and Hyla sanborni (Anura Hylidae) with a description of NOR polymorphism in H nana. J. Hered. 94(2):149-154.
MMA. 2007. Áreas Prioritárias para Conservação, Uso Sustentável e Repartição de Benefícios da Biodiversidade Brasileira: Atualização - Portaria MMA n 9 , de 23 de janeiro de 2007. Ministério do Meio Ambiente, Secretaria de Biodiversidade e Florestas, Brasília.

NAPOLI, M.F. \& CRUZ, I.C.S. 2005. The advertisement call of Hyla atlantica Caramaschi \& Velosa, 1996, with considerations on its taxonomic status (Amphibia, Anura, Hylidae). Arq. Mus. Nac. Rio de Janeiro 63(2):283-288.

NUNES, I., KWET, A. \& POMBAL-JÚNIOR, J.P. 2012. Taxonomic Revision of the Scinax alter Species Complex (Anura: Hylidae). Copeia 2012(3): 554-569.

OLIVEIRA-FILHO, A.T. \& RATTER, A. 2002. Vegetation Physiognomies e Woody Flora of the Cerrado Biome. In The Cerrados of Brazil: Ecology and Natural History of a Neotropical Savanna (P.S. Oliveira \& R.J. Marquis, eds.). Columbia University Press, Nova York, p.91-120.

OLSON, D.M., DINERSTEIN, E., WIKRAMANAYAKE, E.D., BURGESS, N., POWELL, G.V.N., UNDERWOOD, E., D'AMICO, J.A., STRAND, H.E., MORRISON, J.C., LOUCKS, C.J., ALLNUTT, T.F., RICKETTS, T.H., KURA, Y., LAMOREUX, J.F., WETTENGEL, W.W., HEDAO, P. \& KASSEM, K.R. 2001. Terrestrial ecoregions of the world: a new map of life on Earth. Bioscience 51(11):933-938.

PANSONATO, A., MOTT, T. \& STRÜSSMANN, C. 2011 Diversidade de anfíbios anuros em uma area na porção noroeste do Pantanal brasileiro. Biota Neotrop. 11(4):77-86 http://www.biotaneotropica.org.br/v11n4/pt/abstract?article+bn01 711042011 (ultimo acesso em 12/06/2013)

PANSONATO, A., MORAIS, D.H., ÁVILA, R.W., KAWASHITARIBEIRO, R.A., STRÜSSMANN, C. \& MARTINS, I.A. 2012. A new species of Pseudopaludicola Miranda-Ribeiro, 1926 (Anura: Leiuperidae) from the state of Mato Grosso, Brazil, with comments on the geographic distribution of Pseudopaludicola canga Giaretta \& Kokubum, 2003. Zootaxa 3523:49-58.

PANSONATO, A., STRÜSSMANN, C., MUDREK, J.R. \& MARTINS, I.A. 2013. Morphometric and bioacoustic data on three species of Pseudopaludicola Miranda-Ribeiro, 1926 (Anura: Leptodactylidae: Leiuperinae) described from Chapada dos Guimarães, Mato Grosso, Brazil, with the revalidation of Pseudopaludicola ameghini (Cope, 1887). Zootaxa 3620(1):147162.

POMBAL-JÚNIOR., J.P., BILATE, M., GAMBALE, P.G. SIGNORELLI, L. \& BASTOS, R.P. 2011. A New Miniature Treefrog of the Scinax ruber Clade from the Cerrado of Central Brazil (Anura: Hylidae). Herpetologica 67(3):288-299.

REICHLE, S., AQUINO, L., COLLI, G., SILVANO, D., AZEVEDORAMOS, C. \& BASTOS, R. 2004. Dendropsophus nanus. In IUCN 2013. IUCN Red List of Threatened Species. Version 2013.2. http://www.iucnredlist.org (ultimo acesso em 13/12/2013).

RIBEIRO, J.F. \& WALTER, B.M.T. 1998. Fitofisionomias do bioma Cerrado. In Cerrado: Ambiente e Flora (S.M. Sano \& S.P. Almeida, eds.). Embrapa Cerrado, Planaltina, p.89-166. 
SALA, O.E., CHAPIN, F.S.I., ARMESTO, J.J., BERLOW, E., BLOOMFIELD, J., DIRZO, R., HUBER-SANWALD, E., HUENNEKE, L.F., JACKSON, R.B., KINZIG, A., LEEMANS, R., LODGE, D.M., MOONEY, H.A., OESTERHELD, M., POFF, N.L., SYKES, M.T., WALKER, B.H., WALKER, M. \& WALL, D.H. 2000. Global biodiversity scenarios for the year 2100 . Science 287:1770-1774

SILVA, M.P., MAURO, R., MOURÃO, G. \& COUTINHO, M. 2000. Distribuição e quantificação de classes de vegetação do Pantanal através de levantamento aéreo. Rev. Bras. Bot. 23(2):143-152.

SILVA-JUNIOR., N.J., CINTRA, C.E.D., SILVA, H.J.R., COSTA, M.C., SOUZA, C.A., PACHECO-JUNIOR., A.A. \& Gonçalves, F.A. 2009. Herpetofauna, Ponte de Pedra Hydroelectric Power Plant, states of Mato Grosso and Mato Grosso do Sul, Brazil. Check List 5(3):518-525.

SOBERÓN, J. \& LLORENTE, J. 1993. The use of species accumulation functions for the prediction of species richness. Conserv. Biol. 7(3):480-488.

SORIANO, B.M.A. \& GALDINO, S. 2006. Evolução da erosividade das chuvas na bacia do Alto Taquari. In Impactos ambientais e socioeconômicos na Bacia do Rio Taquari - Pantanal (S. Galdino, L.M. Vieira \& L.A. Pellegrin, eds.). Embrapa Pantanal, Corumbá, p.119-124.

SOUZA, F.L., UETANABARO, M., LANDGREF-FILHO, P., PIATTI, L. \& PRADO, C.P.A. 2010. Herpetofauna, municipality of Porto Murtinho, Chaco region, state of Mato Grosso do Sul, Brazil. Check List 6(3):470-475.

STRÜSSMANN, C., PRADO, C.P.A., UETANABARO, M. \& FERREIRA, V.L. 2000. Amphibians recorded during the AquaRAP survey of localities in the southern Pantanal floodplains e surrounding Cerrado, MS, Brasil. In Rapid assessment program, bulletin of biological assessment. A biological assessment of the aquatic ecosystems of the Pantanal, Mato Grosso do Sul, Brasil (P. Willink et al. eds). Conservation International, Washington, p.98-102.
STRÜSSMANN, C., PRADO, C.P.A., FERREIRA, V.L. \& KAWASHITA RIBEIRO, R. 2011. Diversity, ecology, management and conservation of amphibians and reptiles of the Brazilian Pantanal: a review. In: The Pantanal: Ecology, biodiversity ad sustainable management of a large neotropical seasonal wetland (W.J. Junk, C.J. Da Silva \& K.M. Wantzen eds.). Pensoft Publishers. Sofia-Moscow. p.497-521.

UETANABARO, M.O., GUIMARÃES, L.D., BEDA, A.F., FILHO, P.L., PRADO, C.P.A., BASTOS, R.P. \& AVILA, R.W. 2006 Inventário da Herpetofauna no complexo Aporé-Sucuruí. In Biodiversidade do Complexo Aporé-Sucuruí - Subsídios à Conservação e Manejo do bioma Cerrado (Pagotto, T.C.S. e Souza, P.S. eds.). Campo Grande, Editora UFMS. p129-142.

UETANABARO, M., SOUZA, F.L., LANDGREF-FILHO, P., BEDA, A.F. \& BRANDÃO, R.A. 2007. Anfíbios e répteis do Parque Nacional da Serra da Bodoquena, Mato Grosso do Sul, Brasil $\begin{array}{lll}\text { Biota } & \text { N(3):279-289 }\end{array}$ http://www.biotaneotropica.org.br/v7n3/pt/abstract?inventory+ bn01207032007 (ultimo acesso em 12/06/2013).

WWF - WORLD WILDLIFE FUND. 2010. Monitoramento das alterações da cobertura vegetal e uso do solo na Bacia do Alto Paraguai. Disponível em http://www.wwf.org.br/informacoes/bliblioteca/?25181/Monitora mento-das-alteracoes-dacobertura-veget al.-e-uso-do-solo-naBacia-do-Alto-Paraguai (ultimo acesso em 13/12/2013).

YOUNG, B.E., LIPS, K.R., REASER, J.K., IBÁÑES, R., SALAS, A.W., CEDEÑO, J.R., COLOMA, L.A., RON, S., MARCA, E., MEYER, J.R., MUÑOZ, A., BOLAÑOS, F., CHAVES, G. \& ROMO, D. 2001. Population declines and priorities for amphibian conservation in Latin America. Conserv. Biol. 15(5): 1213-1223.

YOUNG B.E., STUART, S.N., CHANSON, J.S., COX, N.A. \& BOUCHER, T.M. 2004. Disappearing Jewels: The Status of New World Amphibians. Natureserve, Arlington.

ZARACHO, V.H. \& HERNANDO, A.B. 2011. The karyotype of Adenomera diptyx (Boettger 1885) (Anura, Leptodactylidae) from northeastern Argentina. Genet. Mol. Biol. 34(1):84-87. 
Appendix 1. List of vouchers collected in the municipality of Camapuã (Mato Grosso do Sul state, Brazil) and deposited at the zoological collection of Universidade Federal de Mato Grosso do Sul - UFMS.

Apêndice 1. Lista do material testemunho coletado no município de Camapuã (estado de Mato Grosso do Sul, Brasil) e depositados na coleção zoológica da Universidade Federal de Mato Grosso do Sul - UFMS.

Species Collection number

Adenomera cf. diptyx

Dendropsophus jimi

Dendropsophus elianeae

Hypsiboas aff. geographicus

Hypsiboas albopunctatus

Leptodactylus furnarius

Pseudopaludicola ternetzi
ZUFMS AMP02669

ZUFMS AMP2659

ZUFMS AMP2660

ZUFMS AMP2642 - 02646, 02652

ZUFMS AMP2665 - 2668

ZUFMS AMP2661 - 2664

ZUFMS AMP2653 - 2657

Appendix 2. List of anuran sample tissue collected in the municipality of Camapuã (Mato Grosso do Sul state, Brazil) and deposited at the zoological collection of Universidade Federal de Mato Grosso do Sul - UFMS.

Apêndice 2. Lista de amostra de tecido de anuros coletada no município de Camapuã (estado de Mato Grosso do Sul, Brasil) e depositados na coleção zoológica da Universidade Federal de Mato Grosso do Sul - UFMS.

\section{Species Collection number}

$\begin{array}{lc}\text { Pseudopaludicola ternetzi } & \text { ZUFMS AMP3408 - 3414 } \\ \text { Pseudopaludicola } \text { cf. saltica } & \text { ZUFMS AMP3415 - 3416 }\end{array}$

Appendix 3. List of anuran vocalizations recorded in the municipality of Camapuã (Mato Grosso do Sul state, Brazil) and deposited at the zoological collection of Universidade Federal de Mato Grosso do Sul - UFMS.

Apêndice 3. Lista de vocalizações de anuros gravadas no município de Camapuã (estado de Mato Grosso do Sul, Brasil) e depositados na coleção zoológica da Universidade Federal de Mato Grosso do Sul - UFMS.
Species
Collection number

$\begin{array}{lc}\text { Hypsiboas punctatus } & \text { ZUFMS D0001 } \\ \text { Leptodactylus furnarius } & \text { ZUFMS D0002 } \\ \text { Pseudopaludicola ternetzi } & \text { ZUFMS D0003 - 5 } \\ \text { Scinax fuscomarginatus } & \text { ZUFMS D0006 }\end{array}$

